\title{
A new genus of groundwater Ameiridae (Copepoda, Harpacticoida) from boreholes in Western Australia and the artificial status of Stygonitocrella Petkovski, 1976
}

\author{
WONCHOEL LEE \\ Department of Life Sciences, College of Natural Sciences, Hanyang University, Seoul 133-791, Korea; e-mail: \\ wlee@hanyang.ac.kr
}

RONY HUYS*

Department of Zoology, The Natural History Museum, Cromwell Road, London SW7 5BD, U.K.; e-mail:

rjh@nhm.ac.uk

\begin{abstract}
SYNOPSIS. Examination of the copepod fauna inhabiting $50 \mathrm{~m}$ deep production bores on Barrow Island (northwestern Australia), resulted in the discovery of an unusual ameirid which cannot be placed in any extant genus. Both sexes are characterized by a unisetose antennary exopod and extreme reduction in the swimming legs (particularly the endopods) and P5. Males lack a defined P6 closing off the single genital aperture and have an extraordinarily large spermatophore. Females similarly display a highly reduced genital field.

The new species shows superficial similarities to both Psammonitocrella Rouch and Stygonitocrella Reid. Hunt \& Stanley, however the combined presence of a sexually dimorphic inner basal spine on P1, a completely fused genital double-somite, reduced antennary exopod and vestigial P5 excludes it from either genus. Some problems in the current classification of freshwater Ameiridae are highlighted, with particular reference to the genus Stygonitocrella. A new genus Neonitocrella is proposed for Stygonitocrella insularis (Miura, 1962).
\end{abstract}

\section{INTRODUCTION}

The arid to semi-arid north-west of Western Australia has a rich stygofauna including the only vertebrate troglobites known to occur in Australasia, the Blind Gudgeon, Milyeringa veritas Whitley, and the Cave Eel, Ophisternon candidum (Mees), and two, supposedly sympatric, congeneric shrimps, Stygiocaris lancifera Holthuis and S. stylifera Holthuis with tethyan affinities (Humphreys, 1993). Recently, the freshwater copepods of the Cape Range karst area have been the subject of intensive study, resulting in the discovery and description of several cyclopoids belonging to the genera Metacyclops Kiefer, Mesocyclops Sars, Microcyclops Claus, Apocyclops Lindberg, Diacyclops Kiefer and Halicyclops Norman (Pesce et al., 1996a-b; Pesce \& De Laurentiis, 1996; De Laurentiis et al., 1999).

Here we report on the discovery of a remarkable harpacticoid in abandoned production bore holes on Barrow Island off the Cape Range coast. Barrow Island has a typical island Ghyben-Herzberg system with a freshwater lens overlying salt water. The hydrology of the superficial karst is little known despite being a production oil field since the early 1960 s and being the target of 'produced water' disposal until recently. It lies on the North West Shelf of Western Australia and up to about $8-10,000$ years ago it would have been part of the mainland (and throughout most of the last few million years) (Humphreys, 2000). The entire island is likely to be an anchialine system but to date an entry point for divers has not been

* Author for correspondence

(C) The Natural History Museum, 2002 found yet. The subterranean fauna contains Thermosbaenacea, Syncarida and a diverse amphipod community including bogidiellids and melitids. Our samples were taken in a long abandoned water production bore ( $47 \mathrm{~m}$ depth) and an abandoned anode bore $(55 \mathrm{~m}$ depth) that was used in the electrolytic protection of the oil wells. The latter would have gassed chlorine and had a $\mathrm{pH}$ of $<2$ when in service (Humphreys, pers. comm).

\section{MATERIALS AND METHODS}

Specimens were dissected in lactic acid and the dissected parts were mounted on slides in lactophenol mounting medium. Preparations were sealed with Glyceel or transparent nail varnish. All drawings have been prepared using a camera lucida on a Zeiss Axioskop differential interference contrast microscope.

Males and females of Inermipes humphreysi gen et sp. nov. were examined with a Philips XL30 scanning electron microscope. Specimens were prepared by dehydration through graded acetone, critical point dried, mounted on stubs and sputter-coated with gold or palladium.

The descriptive terminology is adopted from Huys et al. (1996). Abbreviations used in the text are: ae, aesthetasc; P1-P6, first to sixth thoracopod; $\exp (\mathrm{enp})-1(2,3)$ to denote the proximal (middle, distal) segment of a ramus. Type material is deposited in the collections of the Western Australian Museum, Perth (WAM) and The Natural History Museum, London (BMNH). 


\section{SYSTEMATICS}

Family AMEIRIDAE Monard, 1927

Genus INERMIPES gen. nov.

DiAgNOSIS. Ameiridae. Body elongate, cylindrical, and vermiform without distinct surface ornamentation except for ventral spinule patterns on abdomen. Cephalothorax and other somites with smooth posterior margin. Genital and first abdominal somites completely fused forming double-somite; original segmentation not discernible. Genital field with small copulatory pore located in median depression. Anal operculum well developed.

Sexual dimorphism in antennule, P1 inner basal spine, P5, P6, genital segmentation and abdominal spinulation.

Rostrum fused to cephalothorax, not defined at base. Antennule 8 -segmented in,+ 10 -segmented and subchirocer in $\delta$; segment 1 without seta; aesthetascs on segments 4 and $8(q)$ or on 5 and $10(\delta)$; apical acrothek consisting of minute aesthetasc and 2 setae. Antenna with separate basis and endopod; exopod minute, with 1 seta. Mandible with 2-segmented palp, comprising unarmed basis and endopod with 4 setae. Maxillule with strongly developed arthrite, with 2 naked seta on anterior surface and 8 spines/setae around distal margin; coxa with 2 setae and 1 spine; palp cylindrical with 5 setae, probably representing basis only. Maxilla with trisetose endite on syncoxa; allobasis drawn out in remarkably long claw; endopod a small bisetose segment. Maxilliped with unarmed syncoxa; basis elongate, with very long endopodal pinnate claw.

P1 with 3-segmented rami; basis without outer seta, inner spine sexually dimorphic; exp-1 elongate, exp-2 without inner seta, exp-3 with 4 elements; endopod with formula [1.0.020].

P2-P4 with 3-segmented exopods and 1-segmented endopods. Bases without outer seta. Exp-1 markedly elongate; exp-2 with very strong inner seta; apical setae of exp-3 very long. Endopods minute, with very long apical seta(e). Armature formula:

\begin{tabular}{lll}
\hline & Exopod & Endopod \\
\hline P2 & 0.1 .022 & 010 \\
P3 & 0.1 .022 & 020 \\
P4 & 0.1 .122 & 010 \\
\hline
\end{tabular}

P5 rudimentary with baseoendopod fused to somite and represented only by outer basal seta. Exopod a small segment with 1 seta in $\uparrow$ and 1 multipinnate fused spine plus 1 seta in $\delta$. P6 rudimentary, forming unarmed median operculum in $\$$; asymmetrical in $\delta$ (with dextral or sinistral configuration), represented by opercular unarmed plate.

Caudal ramus short, with 7 setae; seta V longest.

Spermatophore extraordinarily large, longer than half the body length.

TYPE AND ONLY SPECIES. Inermipes humphreysi gen. et sp. nov.

ETYMOLOGY. The generic name alludes to the absence of the outer seta on the bases of the swimming legs. Gender: feminine.

Inermipes humphreysi sp. nov.

TYPE LOCALITY. Barrow Island, Western Australia $\left(37^{\circ} 50^{\prime} 46^{\prime \prime} \mathrm{N}\right.$, $\left.31^{\circ} 31^{\prime} 35^{\prime \prime} \mathrm{W}\right)$, stn BES 792, borehole, 50-55m deep, 1 December 1992.

TYPE MATERIAL. Holotype $q$ dissected on 9 slides (WAM C24414). Paratypes deposited in NHM are 19 dissected on 8 slides $(\mathrm{BMNH}$
1999.1106), BES 792, depth 50-55m, 1 December 1992 and 9 우, 9 o $\delta$ in $70 \%$ alcohol (BMNH 1999.1107-1124), BES 793, 1 December 1992. Paratypes deposited in WAM are (a) 18 dissected on 7 slides, and 4 우, 6 o $\delta$ in 70\% alcohol, BES 792, depth 50-55m, 1 December 1992, (b) 1 t in 70\% alcohol, BES 798, depth 45-50m, 2 December 1992, and (c) 5 우, 15 ơ in $70 \%$ alcohol, BES 810, depth 50-55m, 2 December 1992 (WAM C24415-24417). All specimens are from the type locality and were collected by Dr W.F. Humphreys using a plankton net with a $125 \mathrm{~m}$ mesh and of a size suitable for the borehole (Pesce et al., 1996a).

\section{DESCRIPTION}

FEMALE. Total body length $540-667 \mu \mathrm{m}(\mathrm{n}=10$; mean $=592 \mu \mathrm{m}$; measured from anterior margin of rostrum to posterior margin of caudal rami). Largest width measured at posterior margin of genital double-somite: $106 \mu \mathrm{m}$. Genital double-somite swollen. No distinct demarcation between urosome and prosome (Fig. 1B).

Cephalothorax with smooth posterior margin; pleural areas small and rounded; sensillae and few pores present as illustrated in Fig. 1A-B. Rostrum not defined at base (Fig. 1B), with pair of tiny sensillae near apex.

Pedigerous somites completely smooth. All prosomites without defined hyaline frills; hind margin smooth; separated by large membranous areas. Body not markedly constricted between individual somites. P4-bearing somite distinctly narrower than preceding ones.

Urosome (Fig. 1A-B) 5-segmented, comprising P5-bearing somite, genital double-somite and 3 free abdominal somites. P5bearing somite, and genital double-somite without surface ornamentation, except for dorsal pairs of sensillae. Free abdominal somites with several rows of minute spinules laterally (Fig. 1A) and ventrally (Fig. 2C); hyaline frills of urosomites not present. Ovary large, about half of body length (Fig. 1A-B).

Genital double-somite (Figs 1A-B, 2C) wider than long; completely fused, with weakly pronounced constriction bilaterally (possibly indicating original segmentation). Genital field (Fig. 2C) with small copulatory pore (arrowed in Fig. 2C) located in median depression; gonopores fused medially forming single genital slit covered on both sides by opercula derived from sixth legs; no distinct armature discernible; seminal receptacles fused forming large median sac.

Anal somite (Fig. 2C-D) with well developed spinulose operculum flanked by spinular rows; with pair of dorsal sensillae anterior to operculum. Caudal rami (Fig. 2C-D) longer than wide; each ramus with 7 setae; setae I-III and VI-VII bare, setae IV and V with minute spinules; setae I and II positioned dorsolaterally with seta I being much shorter than seta II; seta III positioned laterally; setae IV and $\mathrm{V}$ fused basally, each with predesigned fracture planes at base; seta V longest (longer than whole urosomal segments combined); seta VI small; seta VII tri-articulate at base. Bases of setae typically surrounded by few tiny spinules. Inner margin of each ramus with dorsolateral concavity.

Antennule (Fig. 3A) 8-segmented, slender; with well developed sclerite around base of segment 1 ; all setae bare. Segment 1 without seta; segment 3 longest; segment 4 with aesthetasc. Armature formula: 1-[0], 2-[7], 3-[7], 4-[2+(1+ae)], 5-[2], 6-[2], 7-[4], 8-[3+ acrothek]. Apical acrothek consisting of slender aesthetasc fused basally to 2 setae. All segments without surface ornamentation.

Antenna (Fig. 3B) 4-segmented. Coxa small, without ornamentation. Basis with spinules along proximal outer margin, and distal inner margin; abexopodal seta absent. Exopod minute, 1-segmented, with 1 pinnate apical seta. Endopod 2-segmented; proximal segment with 2 rows of spinules along abexopodal margin; distal segment 


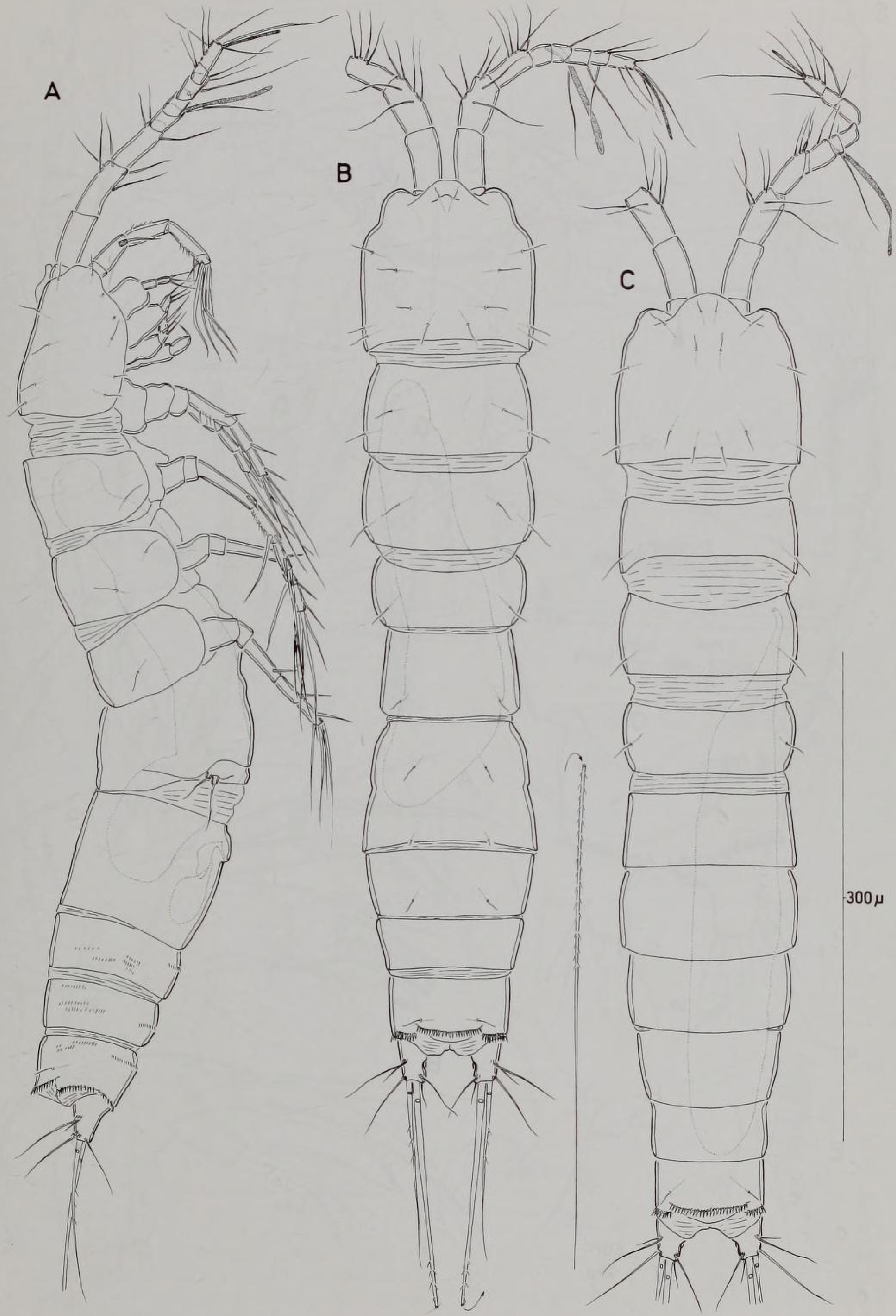

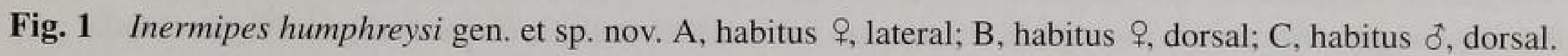



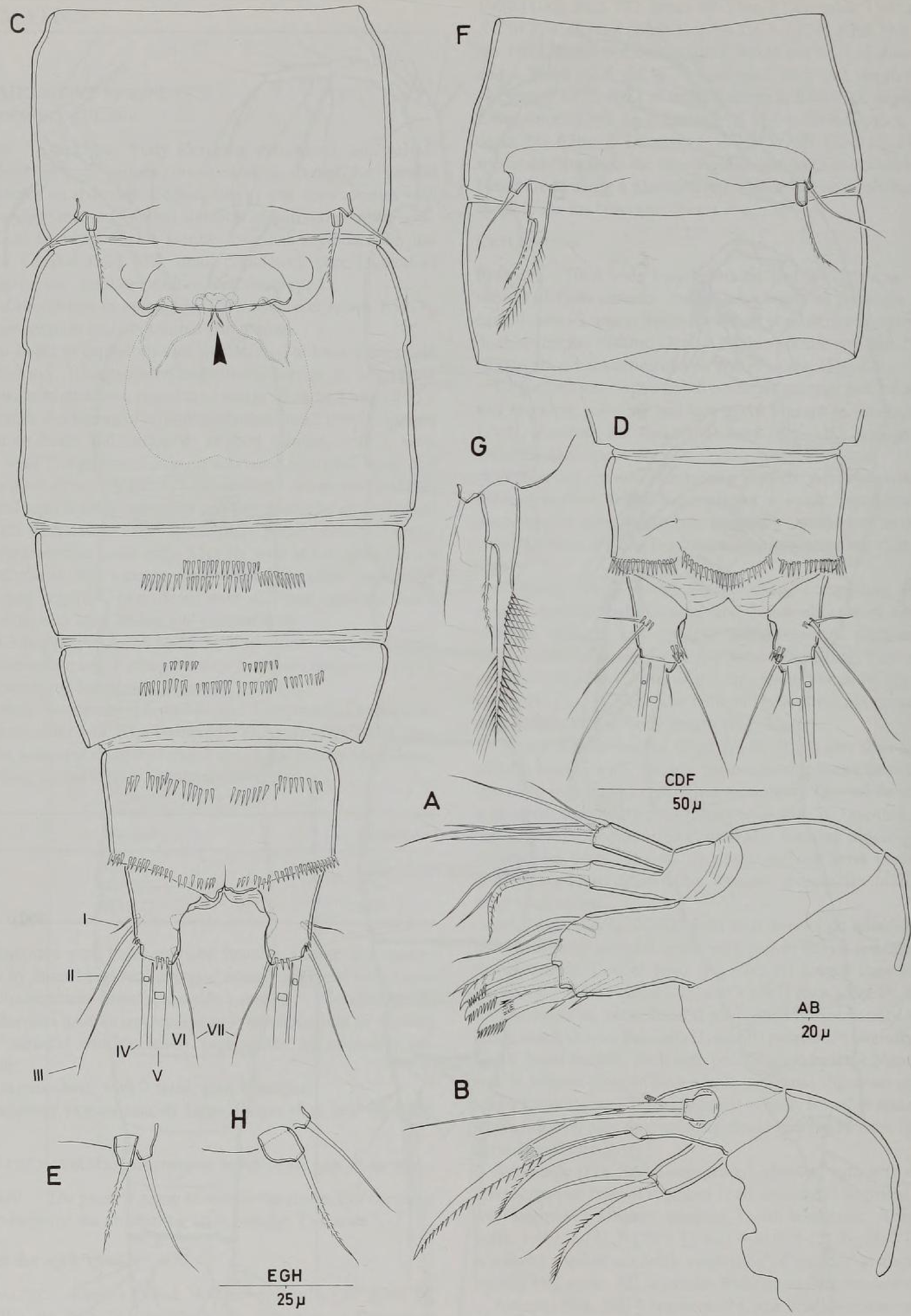

Fig. 2 Inermipes humphreysi gen. et sp. nov. Female: A, maxillule; B, maxilla; C, urosome, ventral [copulatory pore indicated by arrow]; D, anal somite and caudal rami, dorsal; E, P5. Male: F, P5-bearing and genital somites, ventral [P5 aberrant on left side], ventral; G, P5 [normal]; H, P5 [aberrant]. 


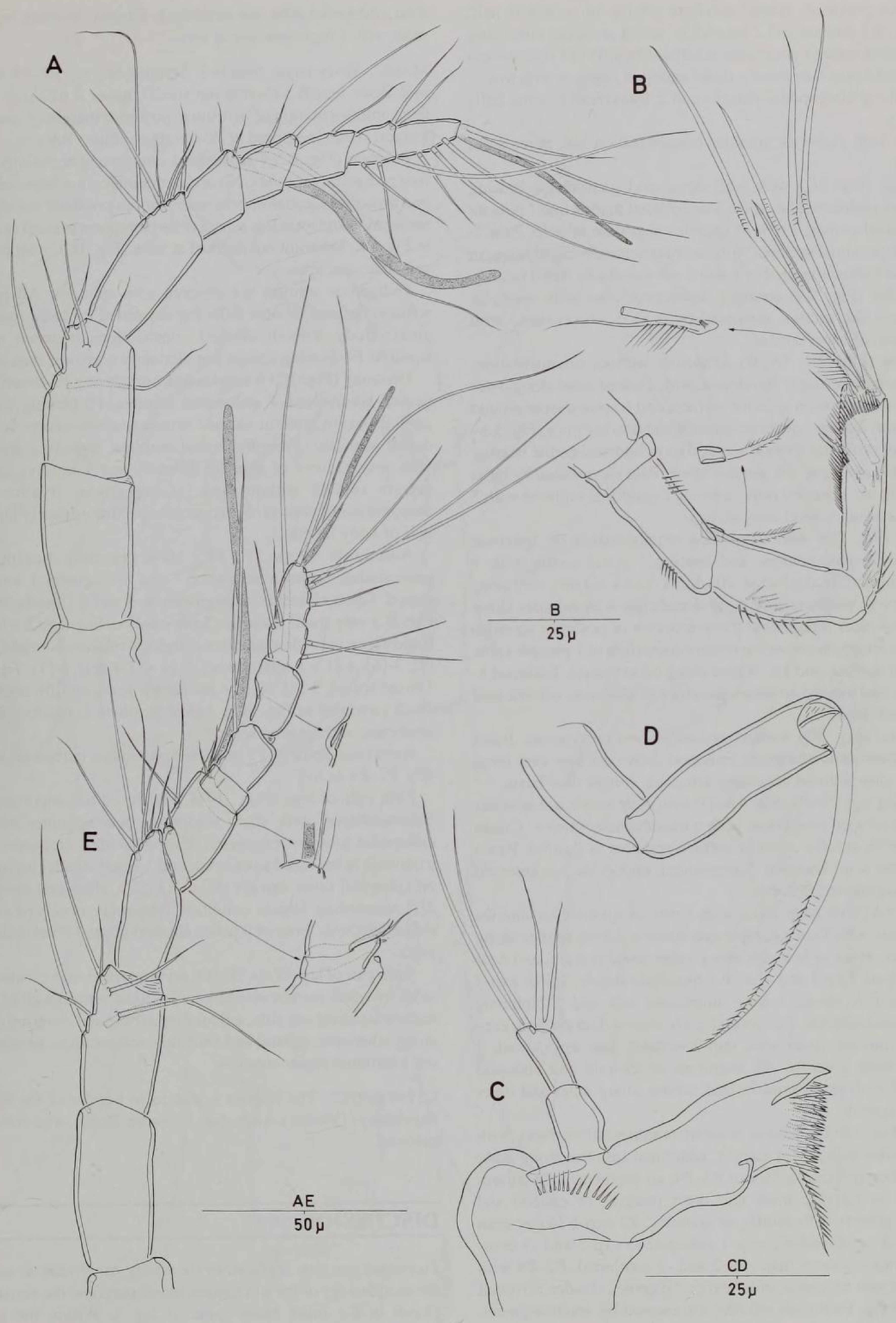

Fig. 3 Inermipes humphreysi gen. et sp. nov. Female: A, antennule; B, antenna; C, mandible; D, maxilliped. Male: E, antennule. 
longer than proximal; lateral armature arising in proximal half, consisting of 1 pinnate and 2 bare setae; apical armature consisting of 5 geniculate setae ( 1 geniculate seta fused basally to 1 pinnate seta and small tube pore; see insert); distal endopod segment with row of spinules along abexopodal margin and 2 transverse hyaline frills subapically.

Labrum with elaborate spinular ornamentation and pores as in Fig. 5A-B.

Mandible (Fig. 3C) with well developed gnathobase bearing several fine, multicuspidate teeth around distal margin and 1 pinnate spine at dorsal corner; 1 row of spinules near base of palp. Palp 2segmented; proximal segment without ornamentation; distal segment with 4 naked setae arranged in 2 pairs; subapical pair fused basally.

Paragnaths (Fig. 5A) strongly developed lobes with medially directed hair-like setules, separated by medial lobe covered with dense pattern of short setules.

Maxillule (Figs 2A, 5A-B). Praecoxa without ornamentation; arthrite elongate, strongly developed, with 2 naked setae along outer margin, 2 short setae on anterior surface, and 6 spines/setae around distal margin; 3 distal spines unipinnate and bearing pore (Fig. $5 \mathrm{~A}-$ B) at base of proximal spinule. Coxa with cylindrical endite bearing 2 naked setae and 1 curved, pinnate spine. Palp represented by basis and possibly incorporated rami, forming cylindrical segment with 5 naked setae around distal margin.

Maxilla (Fig. 2B) without surface ornamentation on syncoxa; medial margin membranous and bearing 1 coxal endite with 1 pinnate spine and 2 naked setae. Allobasis drawn out into very long, slightly curved, unipinnate claw; allobasal claw with spinules along distal half of inner margin and transverse row of posterior spinules halfway the length; accessory armature consisting of 1 pinnate spine on posterior surface, and 1 tube pore along outer margin. Endopod 1segmented, and located on anterior surface of allobasis; ornamented with 2 naked setae.

Maxilliped (Fig. 3D) without ornamentation on syncoxa. Basis smooth without ornamentation. Endopod drawn out into very long, unipinnate claw without accessory armature; longer than basis.

Swimming legs P1-P4 (Fig. 4A-D) with wide intercoxal sclerites and well developed praecoxae, both without ornamentation. Coxae and bases with anterior rows of surface spinules as figured. Bases without outer seta. Exopods 3-segmented, endopods 3-segmented (P1), or 1-segmented (P2-P4).

P1 (Fig. 4A) with large coxa; with 1 row of spinules on anterior surface. Basis with 1 strong, bipinnate spine and long setules along inner margin; rows of spinules along outer distal margin, and near base of exopod. Exp-1 and -2 with 1 bipinnate slender spine; exp-3 with 1 bipinnate spine, 1 long unipinnate seta and 2 bipinnate weakly geniculate setae. Endopod slightly shorter than exopod; enp1 with 1 bipinnate inner seta; enp- 2 without seta; enp-3 with 2 geniculate setae apically. All segments of exopod and endopod ornamented with small spinules and setules along outer and inner margin as figured.

P2-P4 (Fig. 4B-D). Coxae without ornamentation; basis with row of spinules along outer margin; additional spinules along inner margin, and on anterior surface of P3-P4; all segments with pattern of spinules as figured; inner and outer margins of exopod and endopod segments with setules or spinules. P2 exp-1 longer than exp-2 and -3 combined; P3 exp-1 subequal to exp-2 and -3 combined; P4 exp-1 shorter than exp-2 and -3 combined. P2-P4 with strong inner seta on enp-2, outer exopodal spines slender, terminal setae very long. Endopods minute, represented by small segment. Spine and setal formulae as in generic diagnosis.

Fifth pair of legs (Fig. 2C, E) fused to supporting somite. Baseoendopod represented by small, outer setophore bearing basal seta; endopodal lobe not expressed. Exopod forming minute segment with 1 bipinnate apical seta.

MALE. Body larger than in 9 . Somites bearing P2-P4 wider than in + . Body length 515-690 $\mu \mathrm{m}(\mathrm{n}=20$; mean $=622 \mu \mathrm{m}$; measured from anterior margin of rostrum to posterior margin of caudal rami). Largest width measured at P6-bearing somite: $109 \mu \mathrm{m}$.

Prosome (Fig. 1C) 4-segmented, comprising cephalothorax and 3 free pedigerous somites. No distinct demarcation between urosome and prosome. Cephalothorax with smooth posterior margin; pleural areas small and rounded; sensillae and few pores present as illustrated in Fig. 1C. Rostrum not defined at base (Fig. 1C), with pair of tiny sensillae near apex.

Pedigerous somites not covered with spinules. All prosomites without defined hyaline frills but separated by large membranous areas. Body without marked constrictions between individual somites; P4-bearing somite not distinctly narrower than others.

Urosome (Fig. 1C) 6-segmented, comprising P5-bearing somite, genital somite and 4 abdominal somites. P5-bearing somite and genital somite without surface ornamentation, except for pairs of dorsal sensillae. Free abdominal somites, including anal somite, with several rows of spinules laterally and ventrally; dorsal hind margin smooth without any ornamentation. Hyaline frills of urosomites not present. Spermatophore extraordinarily large, about half of body length.

Antennule (Figs 3E, 5C) 10-segmented; haplocer, with geniculation between segments 7 and 8 . Segment 1 longest, unarmed. Some elements on segments 4, 6 and 8 (inserts in Fig. 3E; Fig. 5C) very small. Segment 5 not swollen. Segment 8 with 1 small fused spine in median anterior margin. Armature formula: 1-[0], 2[7], 3-[6], 4-[1 + 1 small spine], 5-[4+(1+ae)], 6-[1], 7-[1], 8-[1+ 1 fused spine], 9-[4], 10-[5 + acrothek]. 1 seta on fifth segment very small [arrowed in Fig. 5C). Apical acrothek consisting of slender aesthetasc and 2 naked setae.

Inner basal spine of P1 modified into robust barbed element (Fig. 4E). $\mathrm{P} 2-\mathrm{P} 4$ as in 9 .

Fifth pair of legs (Figs 2F-H, 5D) fused to supporting somite. Baseoendopod with short setophore bearing outer basal seta; endopodal lobe not expressed. Exopod with 2 elements; 1 apical tripinnate spine fused to exopod, and 1 small slender bipinnate seta on subapical outer margin (Figs 2G, 5D); abnormal exopod (Fig. $2 \mathrm{H})$ resembling female condition frequently observed on one or either side; only 1 out of 9 males showed normal P5 exopod on both sides.

Sixth pair of legs (Figs 2F, 5D) asymmetrical; represented on both sides by small membranous plate (fused to ventral wall of supporting somite along one side; articulating at base and covering gonopore along other side; dextral and sinistral configurations present); without additional ornamentation.

ETYMOLOGY. The species is named in honour of Dr William F. Humphreys (Western Australian Museum, Perth), who collected the material.

\section{DISCUSSION}

Inermipes gen nov. is placed in the family Ameiridae on account of the morphology of the antennules, mouthparts and the sexual dimorphism in the inner basal spine of leg 1. Within the group of freshwater ameirids it can be readily identified by the unisetose antennary exopod, the lack of the outer basal seta on P1-P4 the extreme reduction in the swimming legs (particularly the endopods) 


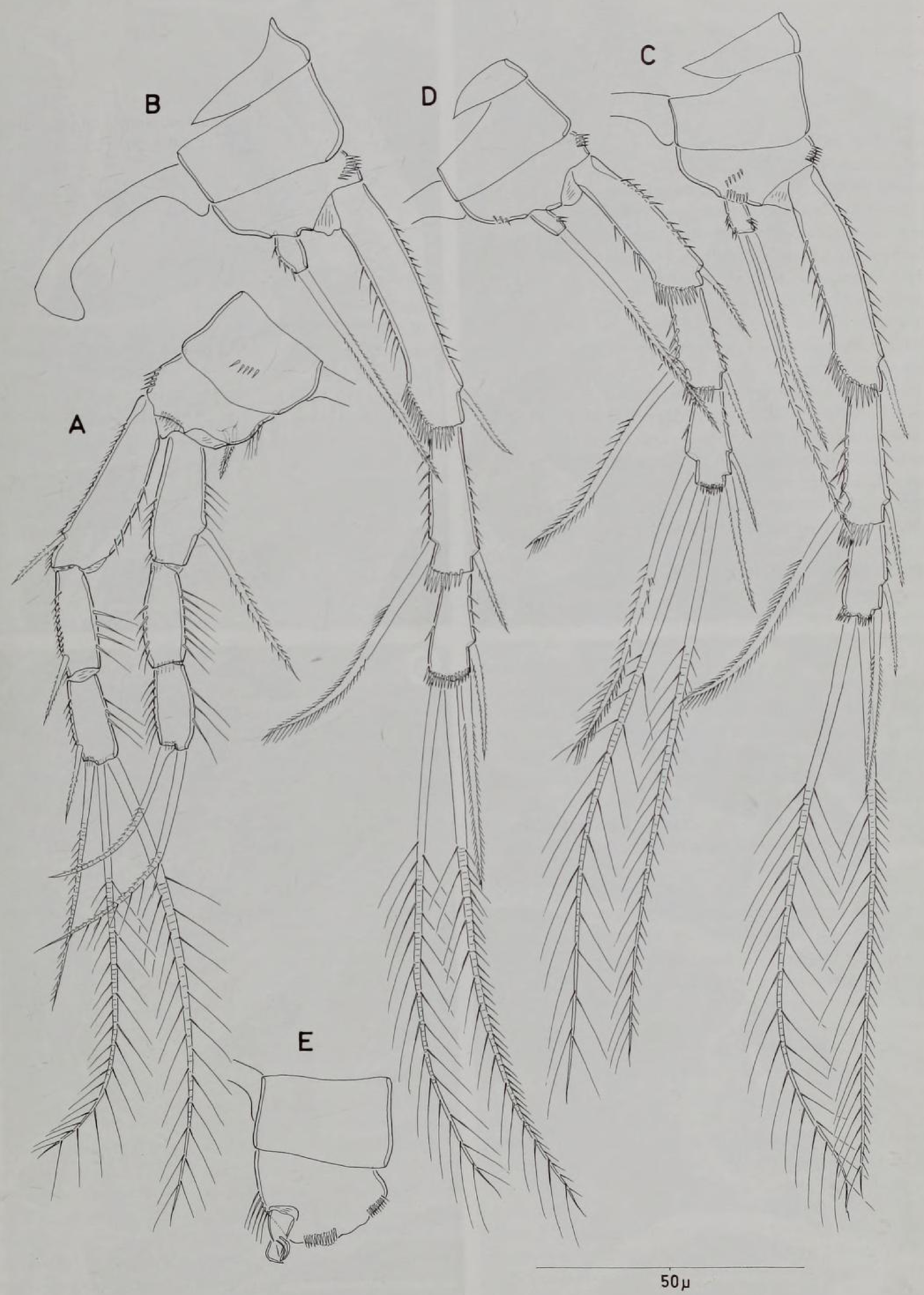

Fig. 4 Inermipes humphreysi gen. et sp. nov. Female: A, P1; B, P2; C, P3; D, P4. Male: E, coxa and basis of P1. 



Fig. 5 Inermipes humphreysi gen. et sp. nov. SEM micrographs. A, oral area showing labrum, paragnath and part of maxillule; B, oral area (different angle); C, antennule $\delta$ [tiny seta on segment 5 arrowed]; D, abdomen ${ }^{\circ}$, showing P5 and P6, ventral. Scale bars: $5 \mu \mathrm{m}$ (A-B), $2 \mu \mathrm{m}$ (C), $20 \mu \mathrm{m}$ (D) 
and the P5. Males lack a defined P6 closing off the single genital aperture and have an extraordinarily large spermatophore. Females similarly display a highly reduced genital field. The size of the spermatophore, occupying nearly half of the body, is remarkable. Except for representatives of the genus Apodopsyllus Kunz (Paramesochridae) where similarly sized spermatophores have been reported, male harpacticoid copepods produce small spermatophores, typically not exceeding the length of two body somites. Given the highly reduced genital apertures of $I$. humphreysi it is difficult to imagine how the spermatophore can be successfully extruded and transferred to the female.

\section{Taxonomy of freshwater Ameiridae}

The primary taxonomic subdivisions in freshwater Ameiridae have traditionally been based on swimming leg segmentation (Lang, 1965; Petkovski, 1976) and have ignored other, more phylogenetically informative characters such as setation patterns and mouthpart morphology (Galassi et al., 1999). This simplistic approach has led to: (1) the generally unsatisfactory practice of describing new species virtually exclusively on leg characters without consideration of cephalic appendages, genital field morphology or even female abdominal segmentation; (2) the establishment of unnatural genera such as Stygonitocrella, and (3) the blurring of generic boundaries. Central to this confusion stands the genus Nitocrella which has served as a taxonomic repository for freshwater Ameiridae since its proposal by Chappuis (1924). Lang (1965) removed all species displaying 3-segmented P2-P4 endopods to a new genus Parapseudoleptomesochra and created a second genus, Pseudoleptomesochrella, to accommodate all Nitocrella species characterized by 2 -segmented $\mathrm{P} 2-\mathrm{P} 4$ endopods and the presence of an inner seta on P2-P4 exp-1. Even under its revised taxonomic concept the genus Nitocrella continued to accumulate a large number of new species which prompted Petkovski (1976) to subdivide the genus even further. He suggested to group only species with 2segmented P2-P4 endopods in Nitocrella s. restr. and to reallocate all remaining species with alternative endopodal segmentation in two new genera, Nitocrellopsis (P2-P3 3-segmented, P4 2-segmented) and Stygonitocrella (P2-P3 1-2-segmented, P4 1 -segmented). Petkovski (1976) also recognized three subgroups in Nitocrella based on the number of armature elements on P4 exp-3: the hirta- (3-4 setae/spines), chappuisi- (5 setae/spines) and vasconica-groups ( 6 setae/spines). Although these groups have met with general acceptance, their monophyletic status has never been challenged. Furthermore, since Petkovski (1976) did not designate a type species for Stygonitocrella, nor for Nitocrellopsis, both generic names were unavailable until recently. Galassi et al. (1999) fixed $N$. rouchi Galassi, De Laurentiis \& Dole-Olivier, 1999 as the type of Nitocrellopsis, making the name available with their authorship. A similar course of action was taken by Reid et al. (in press) who designated S. montana (Noodt, 1965) as the type of Stygonitocrella.

Leg segmentation characters should be used with caution when inferring relationships in derived lineages. For example, the evolutionary instability of endopodal segmentation is illustrated by the genus Psammonitocrella Rouch which contains species with $1-(P$. longifurcata) or 2-segmented $\mathrm{P} 2-\mathrm{P} 3$ endopods ( $P$. boultoni). Unique derived characters such as the loss of the outer spine on P1 exp-2 leave no doubt that both Psammonitocrella species shared a common ancestor, and hence the discrepancy observed in endopodal segmentation has to be interpreted as the result of intrageneric evolution. Utilizing endopodal segmentation patterns in defining generic boundaries is potentially misleading. Overweighing such characters at the expense of others can result in assigning species to the wrong genus. For example, Nitocrella petkovskii Pesce, 1980 and Stygonitocrella colchica (Borutzky \& Michailova-Neikova, 1970 ) are very closely related, differing essentially only in the expression of the segment boundary between P4 enp-1 and -2, but are nevertheless placed in different genera. The close zoogeographical connection between $N$. petkovskii (NW Iran) and S. colchica (W Georgia) is noteworthy in this context.

I. humphreysi shows superficial similarities to both Psammonitocrella and Stygonitocrella, currently the most advanced genera within the Ameiridae, however the combined presence of a sexually dimorphic inner basal spine on P1, a completely fused genital double-somite, reduced antennary exopod and vestigial P5 excludes it from either genus. The genus Psammonitocrella was proposed by Rouch (1992) to accommodate two interstitial species collected in the hyporheic zone of an intermittent desert stream in Arizona. Its familial placement has been questioned by Martinez Arbizu \& Moura (1994) who removed the genus from the Ameiridae and regarded it as the sistergroup of the Parastenocarididae. This course of action was primarily based on the loss of the outer spine of P1 exp-2 and the absence of a sexually dimorphic inner basal spine on leg 1. The juvenile morphology of the P5 in both sexes and the presence of separate genital and first abdominal somites in the adult female strongly suggest a paedomorphic origin for Psammonitocrella. The absence of sexual dimorphism in the inner basal spine of leg 1 should be re-evaluated in this context. The modification of this spine in male Ameiridae appears not until the final moult. Delaying the expression of this character beyond the final moult (post-displacement) would result in the secondary loss of sexual dimorphism. The absence of a modified inner basal spine in Psammonitocrella is therefore to be regarded as autapomorphic and it is proposed here to remove the genus from its floating status and to reallocate it to the Ameiridae.

Similarities between Inermipes and Psammonitocrella are found in the presence of only two setation elements on the distal endopod segment of leg 1, the absence of the outer basal seta in P1-P2, and the reduced $\mathrm{P} 4$ endopod. It is conceivable that these shared characters are the product of convergence since both genera differ significantly in the morphology of the antenna, maxilla, maxilliped and swimming leg ornamentation.

The supposedly cosmopolitan genus Stygonitocrella was diagnosed solely on the basis of the 1-segmented P4 endopod (Petkovski, 1976). Comparison of the swimming leg setal formulae of the 13 species currently included strongly indicates the presence of several discrete lineages within this genus, each exhibiting a typical armature pattern (Table 1) and a restricted geographical distribution (Table 2). This subdivision is admittedly based on swimming leg characters only but we suspect it to be at least partly reinforced by mouthpart and antennulary characters when they become available. Formal recognition of these lineages as distinct genera is impossible since most descriptions are severely lacking in detail and many of them are based on very few specimens or one sex only. For example, the description of $P$. djirgalanica is completely lacking in illustrations (Borutzky, 1978). In addition, the type material of the great majority of its species is no longer extant and additional records have not been added. S. petkovskii differs from its congeners in the absence of the inner seta on $\mathrm{P} 3$ exp-2, an element which is present in all other congeners. Attempts to trace the single female on which this description was based failed (Galassi, pers. comm.).

As pointed out by Reid et al. (in press) the generic placement of S. orghidani (Petkovski, 1973) is questionable. The original description is very concise, showing illustrations only of the antenna, caudal rami and the fifth legs. The exopodal armature of the swimming legs is largely unknown, apart from Petkovski's statement that 


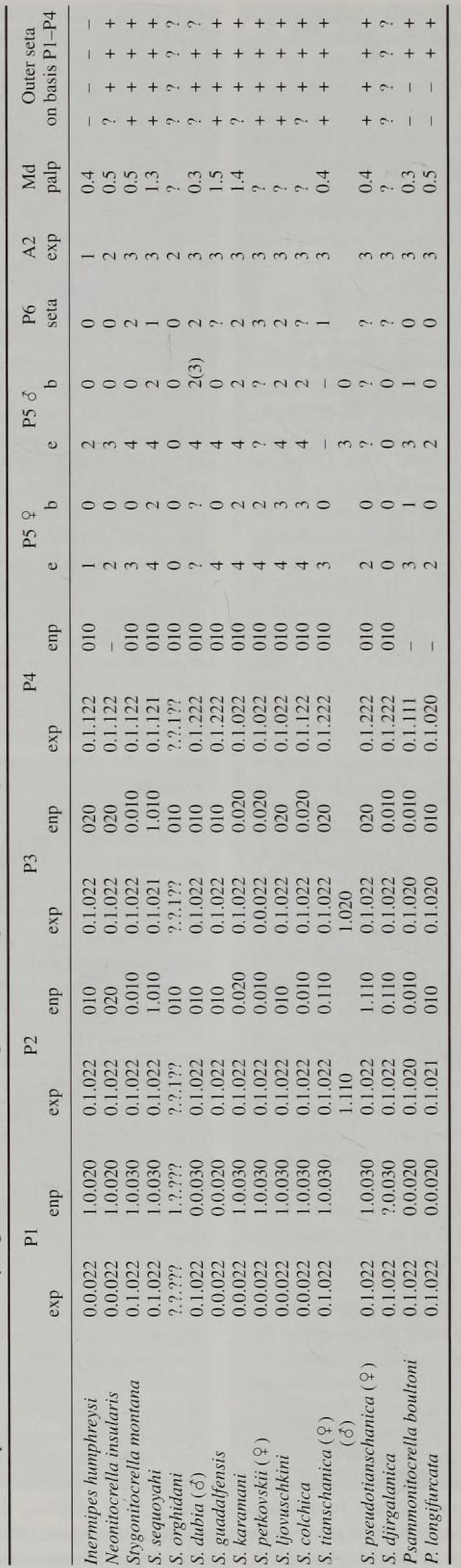


Table 2 Species groups within Stygonitocrella showing zoogeographical connection, habitat and number of specimens known

\begin{tabular}{|c|c|c|c|}
\hline Species & Distribution & Habitat & Material \\
\hline dubia (Chappuis, 1937) & North Spain & cavernicolous & 10 \\
\hline guadalfensis Rouch, 1985 & Andalusia & hyporheic & 9 ㅇ, 4 ठे ठ \\
\hline karamani (Petkovski, 1959) & Macedonia & phreatic & 2 ㅇ, 3 ठे \\
\hline ljovuschkini (Borutzky, 1967) & Ukraine & cavernicolous & 3 के, 2 ठे \\
\hline colchica (Borutzky \& Michailova-Neikova, 1970) & West Georgia & cavernicolous & $3 \% ?, 4$ ठे ठ \\
\hline petkovskii Pesce, 1985 & Lesbos, Greece & phreatic & 19 \\
\hline tianschanica (Borutzky, 1972) & Kirghiztan & phreatic & $2 \circ 9,3 \delta 0$ \\
\hline pseudotianschanica (Štěrba, 1973) & Afghanistan & phreatic & $2 \%$ \\
\hline djirgalanica (Borutzky, 1978) & Kirghiztan & phreatic & $7 \% 9,200$ \\
\hline montana (Noodt, 1965) & Argentina & phreatic & 4 아, 6 ठे ठ \\
\hline orghidani (Petkovski, 1973) & Cuba & cavernicolous & $4 \% ?, 200$ \\
\hline insularis (Miura, 1962) & Ryukyu Islands & phreatic & $2 \% ?, 10$ \\
\hline
\end{tabular}

the distal exopod segment of P2-P4 possesses an inner seta. The species is unusual in having a bisetose antennary exopod and remarkably reduced fifth legs which consist of a median transverse plate retaining only the outer basal setae. Petkovski (1973) points out several similarities between $S$. orghidani and Nitocrella negreai such as the large size of the antennules and antennae, the short caudal rami and the elongate P1 endopod. He regarded these characters as evidence for a distinct lineage within Nitocrella sensu lato. Apart from the 1-segmented P4 endopod there is no evidence for a relationship with any of the other species currently included in Stygonitocrella and in view of its fragmentary description we propose to relegate it to species incertae sedis within this genus.

The only oriental species, $S$. insularis, was described from the Ryukyu archipelago (Miura, 1962a) and shows a number of unique characteristics within Stygonitocrella. It is regarded here as the type species of a new genus Neonitocrella on account of the bisetose antennary exopod, the loss of the P4 endopod (represented by a rudimentary knob) and the reduced P5 in both sexes. The P1 armature pattern, the reduced antennary exopod and the characteristic structure of the male P5 exopod suggest a sistergroup relationship with I. humphreysi, to which it is also closest zoogeographically. Conversely, Nitocrella japonica described from Shikoku Island (Japan) (Miura, 1962b) also shows a remarkable similarity with $I$. humphreysi in the structure of the antenna (unisetose exopod), maxilla (elongate allobasis) and maxilliped (slender basis and claw) but exhibits a more primitive leg formula. This suggests that the genus Inermipes could have been derived from a $N$. japonica-like ancestor through swimming leg reduction.

\section{Genus NEONITOCRELLA gen. nov.}

DiAgnosis. Ameiridae. Body elongate, cylindrical, and vermiform without distinct surface ornamentation except for ventral spinule patterns on abdomen. Cephalothorax and other somites with smooth posterior margin. Genital and first abdominal somites apparently separated. Anal operculum well developed.

Sexual dimorphism in antennule, P3 endopod, P5, P6, and in genital segmentation; unconfirmed for inner basal spine of P1.

Rostrum fused to cephalothorax, not defined at base. Antennule 8segmented in + , unknown in $\delta^{*}$; segment 1 with seta; aesthetascs on segments 4 and possibly 8 in $q$, unknown in $\delta$. Antenna with separate basis and endopod; exopod well developed segment, with 2 setae. Mandible with 2-segmented palp, comprising unarmed basis and endopod with 4 setae. Maxillule, maxilla and maxilliped unconfirmed.

P1 with 3-segmented rami; basis without outer seta; exp-1 not elongate, exp-2 without inner seta, exp-3 with 4 elements; endopod with formula [1.0.020].
P2-P4 with 3-segmented exopods and 1-segmented (P2-P3) or rudimentary (P4) endopods. Bases with outer seta. Apical setae of exp-3 very long. $\mathrm{P} 3$ endopod of with inner distal seta shorter and outer distal spine longer than in $9 . \mathrm{P} 4$ endopod represented by minute knob. Armature formula:

\begin{tabular}{lll}
\hline & Exopod & Endopod \\
\hline P2 & 0.1 .022 & 020 \\
P3 & 0.1 .022 & 020 \\
P4 & 0.1 .122 & - \\
\hline
\end{tabular}

P5 rudimentary with baseoendopod fused to somite and represented only by outer basal seta. Exopod a small segment with 2 setae in $\$$ and 1 pinnate fused spine plus 2 setae in $\delta$. P6 rudimentary, forming unarmed median operculum in $\uparrow$; unconfirmed in $\delta$.

Caudal ramus short, with 7 setae; seta V longest.

TYPE AND ONLY SPECIES. Nitocrella insularis Miura, $1962=$ Neonitocrella insularis (Miura, 1962) comb. nov.

ACKNOWLEDGEMENTS. The authors would like to thank Dr W.F. Humphreys (Western Australian Museum, Australia) for providing us with the copepod material. One of us (W.L.) acknowledges financial support from the Korea Research Foundation provided for the programme year 1997.

\section{REFERENCES}

Borutzky, E.V., 1967. Biospeologica Sovietica XXXII. On the genus Nitocrella Chappuis (Copepoda, Harpacticoida). Byulletin' Moskovskogo Obshchestva Ispytatelei Prirody, Otdel Biolohichesky, New Series 72(3): 32-39. [In Russian].

- 1972. Copepoda Harpacticoida from subterranean water of the shore of Issyk-kul and Southern Kisilkum. Trudy Zoologicheskogo Instituta, Leningrad 51: 98-119.

- 1978. Copepoda Harpacticoida gruntovykh vod tyan'shanya. In: Issledovaniya po faune sovetskogo soyuza (bespozvonochnye I ryby). Sbornik Trudov Zoologicheskogo Muzeya MGU 16: 66-91. [In Russian].

_ \& Mikhailova-Neikova, M. 1970. Harpacticoida (Copepoda) of Caves in West Georgia, Azerbaijan and Middle Asia. Zoologicheskij Zhurnal 49: 1334-1341.

Chappuis, P.A. 1924. Descriptions préliminaires de Copépodes nouveaux de Serbie. Buletinul Societätii de Stiinte din Cluj 2: 27-45.

- 1937. Subterrane Harpacticoiden aus Nord-Spanien. Buletinul Societätii de Stiinte din Cluj 8: 556-571

De Laurentiis, P., Pesce, G.L. \& Humphreys, W.F. 1999. Copepods from ground waters of Western Australia. IV. Cyclopids from basibs and craton aquifers (Crustacea: Copepoda: Cyclopidae). Records of the Western Australian Museum 19:243-257.

Galassi, D.M..P, De Laurentiis, P. \& Dole-Olivier, M.-J. 1999. Nitocrellopsis rouch sp. n., a new ameirid harpacticoid from phreatic waters in France (Copepoda: Harpacticoida: Ameiridae). Hydrobiologia 412: 177-189.

Humphreys, W.F. 1993. Stygofauna in semi-arid tropical western Australia: A Tethyan connection? Mémoires de Biospéologie 20: 111-116. 
2000. The hypogean fauna of the Cape Range peninsula and Barrow Island, North-West Australia. Pp. 581-601. In. H. Wilkens, D.C. Culver \& W.F. Humphreys (eds). Ecosystems of the World. Vol. 30. Subterranean Ecosystems. Elsevier, Amsterdam

Huys, R., Gee, J.M., Moore, C.G. \& Hamond, R. 1996. Synopses of the British Fauna (New Series): Marine and Brackish Water Harpacticoid Copepods Part 1.viii + 352p. Field Studies Council, Shrewsbury, United Kingdom.

Lang, K. 1965. Copepoda Harpacticoida from the Californian Pacific Coast. Kungliga Svenska VetenskapsAkademiens Handlingar (4)10(2): 1-560.

Miura, Y. 1962a. Subterranean harpacticoid copepods of the Amami Group of the Ryukyu Islands. Annotationes zoologicae Japonenses 35: 95-105.

$1962 b$. Three new harpacticoid copepods from subterranean waters of Shikoku in Japan. Japanese Journal of Zoology 13: 267-274.

Noodt, W. 1965. Crustacea subterranea aus Argentinien. Beiträge zur Neotropischen Fauna 4: 84-129.

Pesce, G.L. 1985. Stygobiological researches in subterranean waters of Lesbos (Greece) and description of Stygonitocrella petkovskii n. sp. (Crustacea Copepoda: Ameiridae). Acta Musei Macedonici scientiarum naturalium 12: 125-139.

— $\&$ - 1996. Copepods from ground waters of Western Australia. III. Diacyclops humphreysi n. sp. and comments on the Diacyclops crassicaudis-complex (Copepoda: Cyclopidae). Crustaceana 69: 524-531.

$\longrightarrow$ - \& Humphreys, W.F. 1996a. Copepods from ground waters of Western Australia, I. The genera Metacyclops, Mesocyclops, Microcyclops and Apocyclops
(Crustacea: Copepoda: Cyclopidae). Records of the Western Australian Museum 18 67-76.

-1 - $\&-1996 b$. Copepods from ground waters of Western Australia, II. The genus Halicyclops (Crustacea: Copepoda: Cyclopidae). Records of the Western Australian Museum 18: 77-85.

Petkovski, T.K. 1959. Neue und bemerkenswerte Harpacticoide Ruderfußkrebse (Crust. Cop.) aus den Grundgewässern Jugoslaviens. Acta Musei Macedonici scientiarum naturalium 6: 101-119.

— 1973. Subterrane Süsswasser Harpacticoida von Kuba (Vorläufige Mitteilung). Résultats des Expéditions Biospéologiques Cubano-Roumaines à Cuba 1: 125141.

1976. Drei neue Nitocrella-Arten von Kuba, zugleich eine Revision des Genus Nitocrella Chappuis (s. restr.) (Crustacea, Copepoda, Ameiridae). Acta Musei Macedonici scientiarum naturalium 15: 1-26.

Reid, J.W., Hunt G.W. \& Stanley E.H. (in press). A new species of Stygonitocrella (Crustacea: Copepoda: Ameiridae), the first report of the genus in North America. Proceedings of the Biological Society of Washington, in press.

Rouch, R. 1985. Une nouvelle Stygonitocrella (Copepoda, Harpacticoida) des eaux souterraines d'Andalousie, Espagne. Stygologia 1: 118-127.

- 1992. Une nouveau genre d'Ameiridae (Copepoda, Harpacticoida) dans le milieu hyporhéique d'un cours d'eau de l'Arizona. Stygologia 7: 149-157.

Štèrba, O. 1973. Die neuen Harpacticidenarten der Gattung Nitocrella (Crustacea, Copepoda) aus Afghanistan. Zoologischer Anzeiger 190: 333-342. 